\title{
Phytochemical screening, metal concentration determination, antioxidant activity, and antibacterial evaluation of Drymaria diandra plant
}

\author{
Ashish Phuyal ${ }^{1}$, Pawan Kumar Ojha², Biswash Guragain ${ }^{1}$ and Narendra Kumar Chaudhary ${ }^{1 *}$ [D
}

\begin{abstract}
Background: Several phytochemical constitutes possess natural antioxidant activity and are in fact advantageous in reducing many oxidative stress related diseases. Drymaria diandra of Caryophyllaceae family is one such plant which exhibits various medicinal properties. The aim of the current study is to provide detailed exploration of phytochemical constitutes, metal concentration determination, antioxidant, and antibacterial activity of Drymaria diandra.

Results: Qualitative phytochemical analysis showed the presence of maximum number of metabolites in methanolwater (1:1) extract. The heavy and toxic metals such as $\mathrm{As}, \mathrm{Cd}, \mathrm{Cr}$, and $\mathrm{Pb}$ were almost near to the detection limit. The concentration of Fe $(19.64 \mathrm{mg} / \mathrm{l})$ was highest followed by $\mathrm{Mn}(2.35 \mathrm{mg} / \mathrm{I})$. The $\left(I \mathrm{C}_{50}\right)$ value for methanol extract was found 195.61 which is greater than the standard Ascorbic acid. Antibacterial activity of methanol extract was found higher for Staphylococcus aureus and Escherichia coli with 22-mm and 14-mm sized diameter of zone of inhibition respectively and methanol-water extract for Proteus vulgaris with 17-mm diameter of zone of inhibition.

Conclusion: The findings of the present study showed the presence of various valuable phytochemical constitutes responsible to give antibacterial and antioxidant potency. The presence of bio-metals and the absence of toxic metals further highlight the importance of plant as the source of food that bears medicinal properties.
\end{abstract}

Keywords: Antibacterial, Antioxidant, Drymaria diandra, Phytochemical screening

\section{Background}

The emerging medical problems in commonly employed treatment processes are due to the antimicrobial toxicity and undesirable side effects and are considered the root cause of chemotherapeutic failure which needs extensive investigation to reshuffle drug candidates [1]. Besides their synthetic procurement, several modern drugs with potential activity have been derived from natural resources and so, medicinal plants are focused in research to obtain new chemotherapeutic agents [2]. Plants have played a crucial role in maintaining human health and improving the quality of human life for thousands of

\footnotetext{
*Correspondence: chem_narendra@yahoo.com

'Department of Chemistry, Mahendra Morang Adarsh Multiple Campus,

Biratnagar, Nepal

Full list of author information is available at the end of the article
}

years. The report of $\mathrm{WHO}$ has claimed, $80 \%$ world population relies on traditional medicine for their primary health care needs [3]. The tribes of Nepal have long history of the use of natural products for the successful treatment of chronic diseases [4]. Nepal is a small landlocked country situated in the lap of the great Himalayas in South Asia, bordered by China to the north and India to other three sides. Due to wide variation in biodiversity and geographical distribution, Nepal has considered as one of the richest habitat of medicinal flora and fauna in the world [5]. In more than 6000 species of plants, of which, more than 1600 species with medicinal value are distributed in various climatic zones of Nepal and they offer great possibilities of novel and bioactive compounds. 
Human body requires several biometals for the proper functioning of the systems, either to activate the bioenzymes or to foster immune power in the body [6]. Plants are one such source that can fulfill the requirements in right amount. So the investigation regarding the types of biometals present and their specific concentration in the plants is very essential to highlight their importance in medicinal chemistry [7]. A number of Drymaria species are mentioned as food and for medicinal properties in Ayurvedic and Traditional Chinese Medicine (TCM) [8]. In Nepal, most of the species of drymaria are found in tropical and subtropical parts, extending from southern plane region to northern Himalayan region up to an elevation of $2100 \mathrm{~m}$ height [9]. With insufficient knowledge, this plant has various traditional medicinal uses such as in treating cold, headache, coryza, bronchitis, as poultice on sore (to treat aching, inflamed, or painful parts), leprosy, tumors, as fumigant for eye troubles, as cerebral stimulant and antifebrile agent [10]. But detail investigation on its indigenous use is still a subject of research interest. The present study has aimed to evaluate the phytochemical constitutes and metal concentration determination of Drymaria diandra plant. As its application, we have extended our research to screen antibacterial and antioxidant activity of plant extracts.

\section{Materials}

\subsection{Plant materials}

The whole plant of Drymaria diandra was collected from the wetlands of Sundarharaicha morang, during March 2018. Healthy and mature plants were selected for the study. The taxonomic identification of plant was authenticated by Dr. T. P. Gautam of Department of Botany, Mahendra Morang Adarsh Multiple Campus, Biratnagar and deposited to the department as a sample herbarium. The plants were thoroughly washed with tap water followed by second distilled water to remove the dirt and specks of dust.

\subsection{Drying}

The cleaned plants were cut into small pieces and were left in shade to dry for 10 days. Afterwards, they were dried in hot air oven at $40^{\circ} \mathrm{C}$ for $2 \mathrm{~h}$ to remove the equilibrium moisture before the extraction process.

\subsection{Extraction}

Extraction was performed by Soxhelt extraction technique [11]. Whole plants were pulverized by using a mechanical grinder, which was later sieved through mesh size 80 to get the powder of uniform size. Around $8 \mathrm{~g}$ of the powder was packed in a thimble of filter paper. The apparatus was then assembled and the extractions were carried out using $250 \mathrm{ml}$ each of methanol, hexane, and methanol-water (1:1) as solvent (Fig. 1). The temperature was maintained at $35{ }^{\circ} \mathrm{C}$ for methanol and

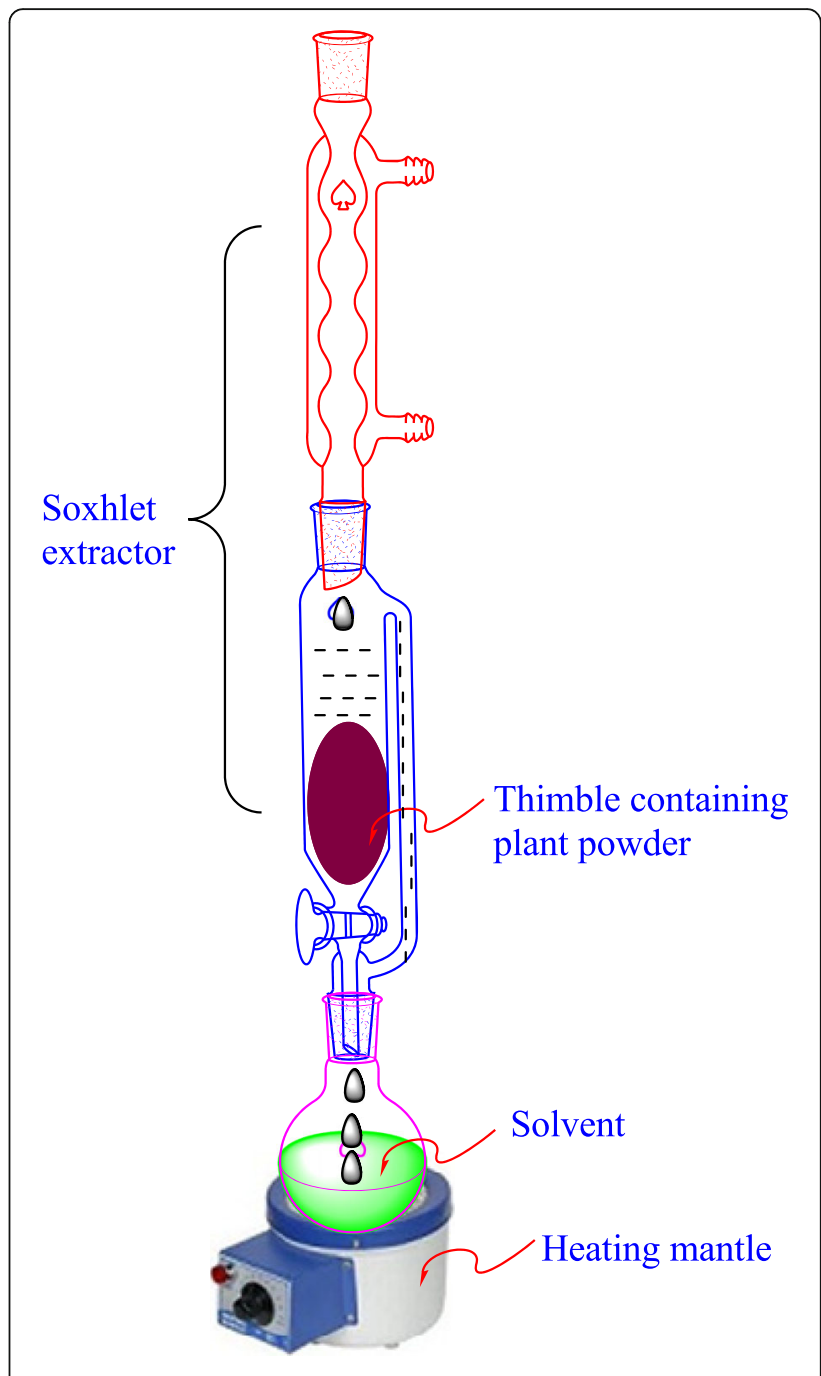

Fig. 1 Soxhlet set up for extraction of crude plant extract

hexane, and $60{ }^{\circ} \mathrm{C}$ for methanol-water (1:1). The extraction was continued for $10 \mathrm{~h}$ for methanol, $5 \mathrm{~h}$ for hexane, and $16 \mathrm{~h}$ for methanol-water (1:1) following the color of the solvent collected in the thimble chamber. Ten milliliters each of concentrated extract was kept for phytochemical screening and remaining extracts were dried. The dried extract was used for antioxidant and antibacterial analysis.

\subsection{Phytochemical screening}

Phytochemical screenings were carried out for hexane, methanol-water, and methanol soluble fractions as per the standard methods [12-15], and following tests were performed:

- Test for alkaloids a. Mayer's test To $2 \mathrm{ml}$ of each extract, few $\mathrm{ml}$ of $2 \mathrm{~N} \mathrm{HCl}$ along with few drops of Mayer's reagent was added. Gelatinous white precipitation confirms the presence of alkaloids. 
b. Wagner test

To $2 \mathrm{ml}$ of extract few drops of Wagner reagent was added, a reddish brown precipitation observed confirms the presence of alkaloids.

- Test for coumarins Few drops of $\mathrm{FeCl}_{3}$ were added in $2 \mathrm{ml}$ of sample; yellow coloration confirms the presence of coumarins.

- Test for saponin

Froth flotation test: $2 \mathrm{ml}$ of sample was added in a test tube with few $\mathrm{ml}$ of water, a froth observed and persisted on constant shaking confirms the presence of saponin.

- Test for tannins and phenolic compound To a $2 \mathrm{ml}$ of extract few drop of $5 \% \mathrm{FeCl}_{3}$ solution was added, blue black precipitation confirms the presence of tannins and phenolic compound.

- Test for flavonoids

To $2 \mathrm{ml}$ of extract, $1 \mathrm{ml}$ of lead acetate solution was added. An intense yellow color was appeared which confirms the presence of flavonoids.

- Test of cardiac glycoside To $2 \mathrm{ml}$ of plant extract, $2 \mathrm{ml}$ of glacial acetic acid containing 1 drop of ferric chloride solution and 1 $\mathrm{ml}$ of concentrated $\mathrm{H}_{2} \mathrm{SO}_{4}$ was added. Appearance of a brown ring indicates the presence of cardiac glycoside.

\section{- Test for reducing sugars}

Fehling test: $1 \mathrm{ml}$ each of Fehling's A and Fehling's $B$ solutions was mixed and boiled for $1 \mathrm{~min}$ and equal volume of test solution was added. The whole solution is heated in a boiling water bath for 5-10 min. Formation of brick red ppt. confirmed the presence of carbohydrate.

- Test of glucoside To $2 \mathrm{ml}$ of plants extract, few drop of concentrated sulfuric acid was added. The presence of black coloration confirms the presence of glucoside.

- Test for anthraquinone
In $2 \mathrm{ml}$ plant extract, $3 \mathrm{ml}$ of benzene and $5 \mathrm{ml}$ of $10 \% \mathrm{NH}_{3}$ were added. Appearance of pink, violet, or red coloration in ammonical layer indicates the presence of anthraquinones.

- Test for glycoside (killer killiani test) To $2 \mathrm{ml}$ of extract, $1 \mathrm{ml}$ of glacial acetic acid, few drop of $\mathrm{FeCl}_{3}$, and few drops of concentrated $\mathrm{H}_{2} \mathrm{SO}_{4}$ were added. Green/blue precipitation indicates the presence of glycoside.

- Test for emodins

To $2 \mathrm{ml}$ of extract, $2 \mathrm{ml}$ of $\mathrm{NH}_{4} \mathrm{OH}$ and $3 \mathrm{ml}$ of benzene were added. Red coloration indicates the presence of emodins.

- Test for phlobatannins To $2 \mathrm{ml}$ of extract, $2 \mathrm{ml}$ of $1 \% \mathrm{HCl}$ was added and heated. Red precipitate indicates the presence of phlobatannins.

- Test for terpenoids To $2 \mathrm{ml}$ of extract, $2 \mathrm{ml}$ of chloroform and $2 \mathrm{ml}$ of concentrated $\mathrm{H}_{2} \mathrm{SO}_{4}$ was added. A reddish brown coloration indicates the presence of terpenoids.

- Test for protein To $2 \mathrm{ml}$ of extract, few drops of concentrated $\mathrm{H}_{2} \mathrm{SO}_{4}$ was added on it. White precipitate indicates the presence of protein.

- Test for steroid (Salkowski test) To $2 \mathrm{ml}$ of extract, $2 \mathrm{ml}$ of $\mathrm{CHCl}_{3}$ and $2 \mathrm{ml}$ of conc. $\mathrm{H}_{2} \mathrm{SO}_{4}$ were added on it. A reddish brown ring at the junction indicates the presence of steroid.

\subsection{Heavy metal concentration test}

The quantification of metals in the plant extract was done by flame AAS technique equipped in ICE 3000 series atomic absorption spectrometer. For this, $1.0 \mathrm{~g}$ of dried sample was taken in a 250-ml conical flask, and 5 ml of conc. $\mathrm{HNO}_{3}$ (GFS Chemicals Inc., Columbus, $69 \%)$ was added slowly. The mixture was heated on the hot plate till the brown fumes disappeared yielding the white fumes. Water was added to make the solution, and it was then filtered in a $50-\mathrm{ml}$ volumetric flask. Finally, the volume was adjusted to $50 \mathrm{ml}$ by adding triple distilled water up to the mark [16, 17]. This filtrate was then introduced in flame AAS for the detection of metals.

\subsection{Antioxidant activity study}

The antioxidant activity of methanol extract was measured by DPPH free radical scavenging assay and it was carried out by Asadujjaman et al. method [18]. The sample solution was prepared in methanol at five different concentrations $(25,50,75,100$, and $150 \mu \mathrm{g} / \mathrm{ml})$. Onemilliliter sample solution of each concentration was thoroughly mixed with 2-ml DPPH solution and shaken well for complete interfusion. The solution was 
Table 1 Phytochemical composition of D. diandra in methanol, methanol-water (1:1) and hexane extract

\begin{tabular}{|c|c|c|c|c|}
\hline S. N. & Phytochemical tests & Methanol extract & Hexane extract & Methanol-water $(1 ; 1)$ extract \\
\hline \multirow[t]{3}{*}{1} & Test for alkaloid & & & \\
\hline & Mayer's test & + & + & ++ \\
\hline & Wagner test & +++ & ++ & +++ \\
\hline 2 & Test for coumarins & + & + & + \\
\hline 3 & Test for saponin & + & + & + \\
\hline 4 & Test for phenol & - & - & - \\
\hline 5 & Test for flavonoids & + & - & + \\
\hline 6 & Test for glycoside & ++ & - & +++ \\
\hline 7 & Test for glucoside & ++ & - & +++ \\
\hline 8 & Test for reducing sugar & - & + & +++ \\
\hline 9 & Test for steroid & + & + & ++ \\
\hline 10 & Test for tannins & - & - & - \\
\hline 11 & Test for protein & - & + & - \\
\hline 12 & Test for tarpenoids & + & + & + \\
\hline 13 & Test for emodins & - & - & - \\
\hline 14 & Test for anthraquinines & - & - & + \\
\hline 15 & Test for cardiac glycoside & - & - & ++ \\
\hline
\end{tabular}

+++ high concentration, ++ medium concentration, + low concentration, and - absent

incubated in dark for $30 \mathrm{~min}$ at room temperature for complete reaction with DPPH and the absorbance was measured at $517 \mathrm{~nm}$ by a UV/Vis. spectrophotometer against blank. The free radical scavenging activity of sample was calibrated in terms of \% age inhibition of DPPH radical and compared with ascorbic acid as standard. The \% age inhibition of DPPH radical is

$$
I \%=\frac{A_{o}-A}{A_{o}} \times 100
$$

where $I$ represents DPPH inhibition (\%), $A_{o}$ is the absorbance of control sample, and $A$ is the absorbance of a tested sample at the end of the reaction. The antioxidant

Table 2 Concentration of different heavy metal (mg/l) in a plant sample

\begin{tabular}{lll}
\hline S. N. & Metals & Concentration $(\mathrm{mg} / \mathrm{l})$ \\
\hline 1 & Iron (Fe) & 19.64 \\
2 & Nickel (Ni) & 0.09 \\
3 & Zinc (Zn) & 1.44 \\
4 & Arsenic (As) & $<0.005$ \\
5 & Cadmium (Cd) & $<0.003$ \\
6 & Chromium (Cr) & $<0.05$ \\
7 & Lead (Pb) & $<0.01$ \\
8 & Manganese (Mn) & 2.35 \\
9 & Cobalt (Co) & 0.23 \\
\hline
\end{tabular}

activity of the sample was also expressed in terms of $\mathrm{IC}_{50}$ value, which represents the concentration of sample required to inhibit 50\% formation of DPPH radical [1921].

\subsection{Antibacterial activity study}

Antibacterial activity study was used to examine the antibacterial potency of the extracted plant sample. The antibacterial study was performed in the laboratory of the Department of Microbiology at Mahendra Morang Adarsh Multiple Campus, Biratnagar. The pathogenic bacteria used in the study were collected from the biochemistry laboratory of Suraksha Hospital, Biratnagar, Nepal.

The agar diffusion test (Kirby-Bauer (KB) antibiotic testing, also called disc diffusion antibiotic sensitivity testing) is a well-known standard method for testing the antibacterial sensitivity of bacteria. The samples (methanol, hexane, and methanol-water (1:1) extract) were tested in vitro against some gram positive and gram negative human pathogenic bacteria; namely Escherichia coli, Proteus vulgaris, and Staphylococcus aureus. Wellsterilized Whatman paper discs of 5-mm size were used as antibiotic assay discs. The discs were made by punching machine and well dried. Firstly, all the glassware, paper disc, and the Mueller-Hinton agar (MHA) media were sterilized. Twenty-five milliliters of MHA was carefully poured into each petri discs and allowed to rest for an hour in the sterilized zone for solidification. Freshly revived bacterial culture was wiped all over the media 
Table 3 Antioxidant activity data of methanol extract

\begin{tabular}{llllll}
\hline S.N. & Concentration $(\mu \mathrm{g} / \mathrm{ml})$ & Absorbance & $\%$ inhibition & $I C_{50}(\mu \mathrm{g} / \mathrm{ml})$ of sample & $I C_{50}(\mu \mathrm{g} / \mathrm{ml})$ of ascorbic acid \\
\hline 1 & 25 & 0.528 & 4.86 & & \\
2 & 50 & 0.413 & 25.53 & 195.61 & 39.25 \\
3 & 75 & 0.386 & 30.45 & \\
4 & 100 & 0.375 & 32.3 & \\
5 & 150 & 0.358 & 35.45 & \\
\hline
\end{tabular}

using sterile swab and the discs were stuck over it. Consequently, these discs were supplied with test compounds at three different concentrations $(150,75$, and $37.5 \mu \mathrm{g} / \mu \mathrm{l}$ in DMSO). One of the disc was soaked in DMSO and used as the solvent control, while amikacin (30 $\mu \mathrm{g} / \mathrm{disc})$ was used as positive control. The whole process was carried out under UV laminar flow to eliminate the bacterial contamination, and the loaded discs were dried within the laminar flow chamber. The inoculated plates were incubated at $37{ }^{\circ} \mathrm{C}$ for $24 \mathrm{~h}$. Also, the diameter of the zone of inhibition was measured by using anti-biogram zone measuring scale. The results were interpreted using the chart of NCCLS.

\section{Results}

\subsection{Phytochemical screening}

The phytochemical screening revealed the presence of alkaloids, saponins, coumarins, steroids, and terpenoids, in all three hexane, methanol, and methanol-water (1:1) extracts [22]. Flavonoids, glycosides, and glucosides were present in methanol and methanol-water extract but were absent in hexane extract. Protein was found to be present only in hexane extract. Anthraquinones and cardiac glycoside were present only in methanol-water extract whereas tannins, phenols, and emodins were absent in all three extracts.
The concentration of alkaloid by Mayer's test was medium in the methanol-water extract and low in remaining other two extracts. Similarly, in Wagner's test, it was high in methanol and methanol-water (1:1) and low in hexane extract. Coumarins, saponins, and terpenoids were present in low concentration in all three extracts. The concentration of Flavonoids was low in methanol and methanol-water (1:1) extract, whereas it was absent in hexane extract. Glycoside and glucosides were found to be in the high concentration in methanol and methanol-water (1:1) extracts and were absent in hexane extract. The reducing sugar was at high concentration in methanol-water (1:1) extract, low in hexane, and absent in methanol extract. Proteins were present only in hexane extract with low concentration. Anthraquinones were found present in low concentration and cardiac glycoside in medium concentration in methanolwater (1:1) extract and were absent in remaining two extracts. The report of phytochemical screening is presented in Table 1.

\subsection{Heavy metal concentration test}

Table 2 reports metal concentration data in $\mathrm{mg} / \mathrm{l}$ of the plant sample. The inspection of data revealed higher concentration of $\mathrm{Fe}(19.64 \mathrm{mg} / \mathrm{l})$ followed by $\mathrm{Mn}, \mathrm{Zn}$, $\mathrm{Co}$, and Ni. The remaining 4 metals $\mathrm{As}, \mathrm{Cd}, \mathrm{Cr}$, and $\mathrm{Pb}$

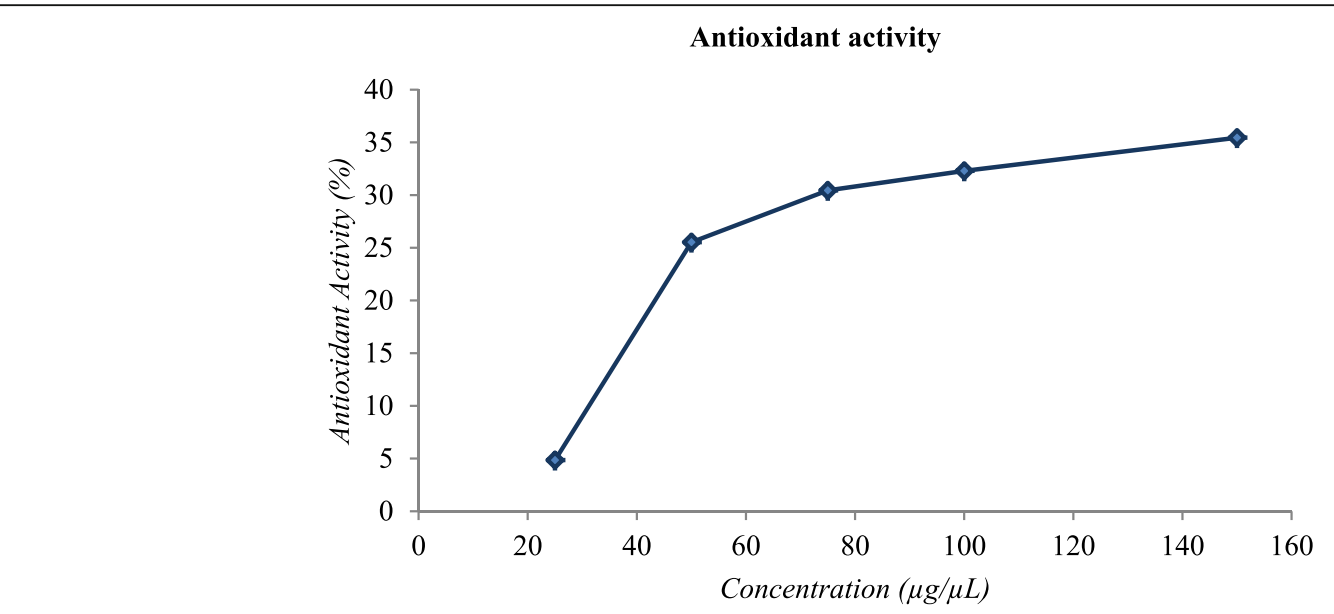

Fig. 2 Graphical plot for antioxidant activity study 
Table 4 Antibacterial data of methanol, hexane, and methanol water (1:1) extracts of $D$. diandra in DMSO

\begin{tabular}{|c|c|c|c|c|c|c|c|c|c|}
\hline \multirow{3}{*}{$\begin{array}{l}\text { Plant extract } \\
{\text { Conc }{ }^{n} \cdot(\mu g / \mu l)}\end{array}$} & \multicolumn{9}{|c|}{ Diameter of zone of inhibition in $\mathrm{mm}$} \\
\hline & \multicolumn{3}{|l|}{ E. coli } & \multicolumn{3}{|l|}{ S. aureus } & \multicolumn{3}{|l|}{ P. vulgaris } \\
\hline & 150 & 75 & 37.5 & 150 & 75 & 37.5 & 150 & 75 & 37.5 \\
\hline Methanol & $14 \pm 0.577$ & $13 \pm 0.577$ & $11 \pm 1.0$ & $22 \pm 1.0$ & $15 \pm 1.0$ & $12 \pm 0.577$ & $12 \pm 0.577$ & $11 \pm 0$ & $10 \pm 0.577$ \\
\hline Hexane & $12 \pm 0.577$ & $11 \pm 1.0$ & $10 \pm 1.0$ & $15 \pm 0.577$ & $14 \pm 0.577$ & $13 \pm 0.577$ & $11 \pm 0.577$ & $11 \pm 0.577$ & $10 \pm 0.577$ \\
\hline Methanol-water (1:1) & $13 \pm 0$ & $11 \pm 1.0$ & $10 \pm 0.577$ & $13 \pm 0.577$ & $12 \pm 0.577$ & $11 \pm 0.577$ & $17 \pm 1.0$ & $11 \pm 0.577$ & $10 \pm 0$ \\
\hline Amikacin & $18 \pm 0.577$ & & & $18 \pm 0.577$ & & & $15 \pm 0.577$ & & \\
\hline
\end{tabular}

were found in very little amount which is nearly below the detection limit.

\subsection{Antioxidant activity study}

The methanol extract of Drymaria diandra was assessed for DPPH free radical scavenging activity and the results are presented in Table 3. Figure 2 shows graphical plot of concentration verses \% antioxidant activity inhibition of DPPH radical and from this plot, $\mathrm{IC}_{50}$ value was calculated. Lower $\mathrm{IC}_{50}$ value signifies higher antioxidant activity [23]. $\mathrm{IC}_{50}$ value of control (i.e., ascorbic acid) was found to be $39.25 \mu \mathrm{g} / \mathrm{ml}$. In the present study, the $\mathrm{IC}_{50}$ value of the plant extract was found approx. 5 times greater than that of ascorbic acid.

\subsection{Antibacterial activity study}

The values of the diameter of the zone of inhibition of the tested bacterial pathogen for different extracts in three different concentrations are presented in Table 4 and are depicted in the bar graph below (Figs. 3, 4, and $5)$. These values of diameter of zone of inhibition correspond to the antibacterial strength of the extracts. The result shows interesting dose dependent antibacterial activity of the extract. All three extracts have shown activity against all bacterial pathogens but as compared with methanol and methanol-water extract, hexane extract showed little activity against all the bacterial pathogens.
It is observed that hexane and methanol extracts were most active against $S$. aureus, and methanol-water extract (at the concentration $150 \mu \mathrm{g} / \mu \mathrm{l}$ ) was active against P. vulgaris even more than the control drug Amikacin. Similarly, all three extracts showed higher inhibition of S. aureus at the concentration $75 \mu \mathrm{g} / \mu \mathrm{l}$ and $37.5 \mu \mathrm{g} / \mu \mathrm{l}$ as compared with $P$. vulgaris and E. coli.

\section{Discussion}

The plant metabolites are essential chemicals that exhibit several noticeable effects in the human body. Flavonoids possess potent antioxidant activities and alkaloids show anticancer antimalarial activities. Steroids are very important class of alcohols with varying significance. The structures are so suited to be effectively transformed by the microbial actions to commercially valuable compounds which are otherwise difficult to synthesize [24]. The presence of steroids in all extracts posed an unlimited hope. The saponins are also known as the soap forming compounds and are economically important. The anthraquinones are naturally occurring coloring compounds used in food, drugs, cosmetics, etc. [25]. The Drymaria diandra plant inhabiting in Sundarharaicha region is found to accumulate much important class of compounds possessing therapeutic as well as commercial values. Furthermore, the area from where the plant was selected was free from metal pollution, and so

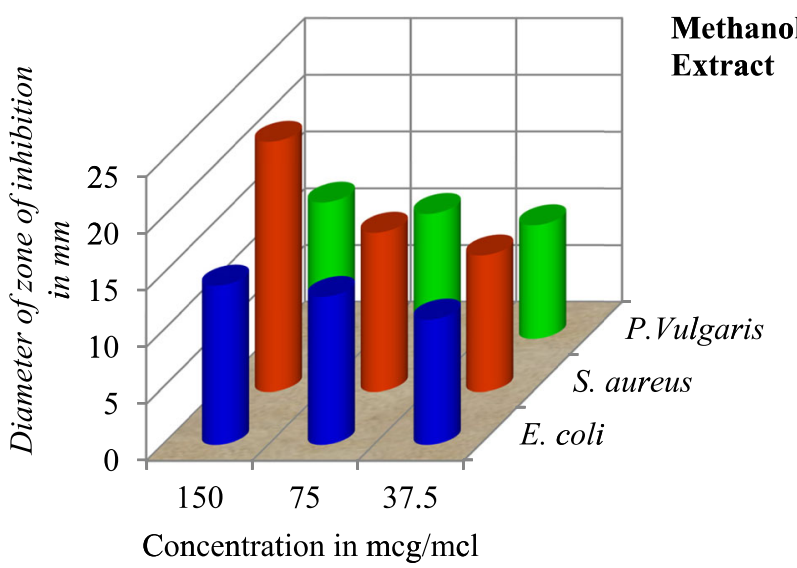

- E. coli

S. aureus

P.Vulgaris

Fig. 3 Antibacterial sensitivity of methanol extract 


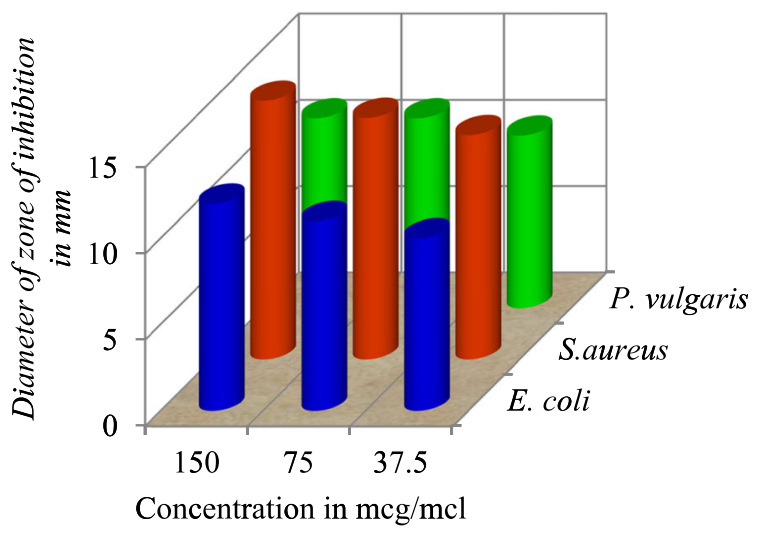

Hexane

Extract

- E. coli

- S.aureus

- P. vulgaris

Concentration in $\mathrm{mcg} / \mathrm{mcl}$

Fig. 4 Antibacterial sensitivity of hexane extract

the plant is edible. Several metals were present in trace amount which is beneficial for several biological activities. The presence of iron suggests that the plants can be useful in the preparation of the drug for the treatment of anemia.

This low antioxidant activity of the plant extract may be due to absence of phenolic compounds and trace presence of flavonoids [26]. These are the chief components of plant extracts that are responsible to show the antioxidant activity in the living systems, acting as radical scavenger. The phenolic compounds do play the role of free radical scavenger and protect body from oxidative damage [27]. Over production of free radicals can cause oxidative stress in the living body which is associated to oxidative destruction of proteins, nucleic acids, and lipids. This destruction may lead to severe chronic degenerative diseases [28]. The current research result reveals less potency of antioxidant activity of Drymaria diandra plant.

The extracts showed a good spectrum of concentration dependent antibacterial actions against the tested pathogenic bacteria. So this plant may be useful for the preparation of broad spectrum antibacterial drugs. To sum up, this study is a good support for varied folklore uses of the Drymaria diandra plant.

\section{Conclusion}

Various phytochemicals, including alkaloids, steroids, glycosides, anthraquinones, etc., are present, while tannins and emodins were found absent in this plant. The presence of essential metals like $\mathrm{Fe}, \mathrm{Zn}$, and $\mathrm{Mn}$ in trace amount and the absence of toxic metals like $\mathrm{Pb}, \mathrm{Cd}$, and As provide biological significance of the studied plant. The paper disc diffusion test showed some good antibacterial potency, comparable to the standard antibiotics. Antioxidant potency shown by the plant is sure to maintain the free radicals in the body, and scavenge them if they are high and a very good defender to the DNA. Still, a large segment of the population in the world relies upon the traditional system of medicine. The folklore use though is very resourceful; the authenticity yet

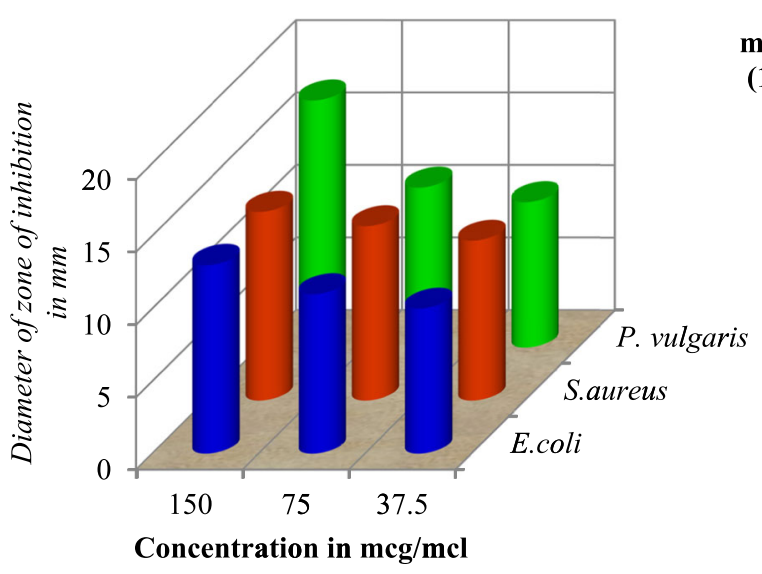

methanol - water

(1:1) Extract

- E.coli

- S.aureus

- P. vulgaris

Fig. 5 Antibacterial sensitivity of methanol-water (1:1) extract 
needs serious research. The closely resembling species may sometimes create ambiguity that even leads to fatal disorders. Nepal, being a very rich source of vegetation, possesses an untapped reservoir with infinite possibility of medicinal species, and yet, we are poor. Therefore, there is an urgent need for improved management and investigation of such plants that bilaterally would upgrade her economy and promote the health worldwide. In the meantime, the bleak field of antibiotics is literally crying of resistance. Moreover, such natural antibiotics can have potential advantages over bacterial infections as resistance could somehow be detained. D. diandra may be one of the alternatives. With more resources and time, further investigation of chemical constituents of $D$. diandra and other poorly studied plants can be revealed.

\section{Abbreviations}

AAS: Atomic absorption spectroscopy; DMSO: Dimethyl sulfoxide; DPPH: 2,2Diphenyl-1-picrylhydrazyl; $I C_{50}$ : Half maximal inhibitory concentration; KB: Kirby-Bauer; MHA: Mueller-Hinton agar; MMAMC: Mahendra Morang Adarsh Multiple Campus; NCCLS: National Committee for Clinical Laboratory Standard; TCM: Traditional Chinese Medicine

\section{Acknowledgements}

The authors are thankful to Prof. P. Mishra for his valuable suggestions and inspiring words. We are also grateful to the Department of Chemistry, MMAMC Biratnagar for providing necessary chemicals to pursue the research work.

\section{Authors' contributions}

AP and BG performed the study. NKC supervised the work and PKO managed antioxidant activity work. All authors have read and approved the manuscript.

\section{Funding}

This study has no funding.

\section{Availability of data and materials}

All the data generated and analyzed during the study are included in the manuscript and are available for the readers.

\section{Ethics approval and consent to participate}

Not applicable.

\section{Consent for publication}

Not applicable.

\section{Competing interests}

The authors declare that they have no competing interests.

\section{Author details}

${ }^{1}$ Department of Chemistry, Mahendra Morang Adarsh Multiple Campus, Biratnagar, Nepal. ${ }^{2}$ Central Department of Chemistry, Tribhuvan University, Kirtipur, Kathmandu, Nepal.

Received: 8 September 2019 Accepted: 23 October 2019

Published online: 09 December 2019

\section{References}

1. Brunetti J, Falciani C, Roscia G et al (2016) In vitro and in vivo efficacy, toxicity, bio-distribution and resistance selection of a novel antibacterial drug candidate. Sci Rep 6:1-12

2. Zaid H, Silbermann M, Amash A, Gincel D, Abdel-Sattar E, Sarikahya NB (2017) Medicinal plants and natural active compounds for cancer chemoprevention/chemotherapy. Evid Based Complement Altern Med. https://doi.org/10.1155/2017/7952417
3. Ekor M (2014) The growing use of herbal medicines: issues relating to adverse reactions and challenges in monitoring safety. Front Pharmacol 4 : $1-10$

4. Kunwar RM, Mahat L, Acharya RP, Bussmann RW (2013) Medicinal plants, traditional medicine, markets and management in far-west Nepal. J Ethnobiol Ethnomed 9:1-10

5. Bhattarai S, Chaudhary RP, Quave CL, Taylor RSL (2010) The use of medicinal plants in the trans-himalayan arid zone of Mustang district, Nepal. J Ethnobiol Ethnomed 6:1-11

6. Pokusa M, Trancikova AK (2017) The central role of biometals maintains oxidative balance in the context of metabolic and neurodegenerative disorders. Oxid Med Cell Longev. https://doi.org/10.1155/2017/8210734

7. Osredkar J, Sustar N (2014) Copper and zinc, bological role and significance of Copper/Zinc imbalance. J Clin Toxicol S 3:1-18

8. Patwardhan B, Warude D, Pushpangadan P, Bhatt N (2005) Ayurveda and traditional Chinese medicine: a comparative overview. Evid Based Complement Altern Med 2:465-473

9. Singh AG, Kumar A, Tewai DD (2012) An ethnobotanical survey of medicinal plants used in Terai forest of western Nepal. J Ethnobiol Ethnomed. https:// doi.org/10.1086/1746-4269-8-19

10. Burkill HM (1985) The useful plants of west tropical Africa, 2nd ed ${ }^{n}$. Royal Botanic Gardens, Kew. University Press of Virginia.

11. Azwanida N (2015) A review on the extraction methods use in medicinal plants, principle, strength and limitation. Med Aromat Plants 4:3-8

12. Gavamukulya Y, Abou-Elella F, Wamunyokoli F, AEl-Shemy H (2014) Phytochemical screening, anti-oxidant activity and in vitro anticancer potential of ethanolic and water leaves extracts of Annona muricata (Graviola). Asian Pac J Trop Med 7:S355-S363

13. Aiyegoro OA, Okoh Al (2010) Preliminary phytochemical screening and In vitro antioxidant activities of the aqueous extract of Helichrysum longifolium DC. BMC Complement Altern Med. https://doi.org/10.1186/ 1472-6882-10-21

14. Geetha TS, Geetha N (2014) Phytochemical screening, quantitative analysis of primary and secondary metabolites of Cymbopogan citratus (DC) stapf. Leaves from Kodaikanal hills, Tamilnadu. Int J PharmTech Res 6:521-529

15. Kaur GJ, Arora DS (2009) Antibacterial and phytochemical screening of Anethum graveolens, Foeniculum vulgare and Trachyspermum ammi. BMC Complement Altern Med. https://doi.org/10.1186/1472-6882-9-30

16. Kostic D, Mitic S, Zarubica A, Mitic M, Velickovic J, Randjelovic S (2011) Content of trace metals in medicinal plants and their extracts. Hem Ind 65: 165-170

17. Randjelovic SS, Kostic DA, Zarubica AR, Mitic SS, Mitic MN (2013) The correlation of metal content in medicinal plants and their water extracts. Hem Ind 67:585-591

18. Asadujjaman M, Hossain MA, Karmakar UK (2013) Assessment of DPPH free radical scavenging activity of some medicinal plants. Pharmacologyonline 1 : 161-165

19. Mimica-Dukić N, Bozin B, Soković M, Mihajlović B, Matavulj M (2003) Antimicrobial and antioxidant activities of essential oils of three Mentha species essential oils. Planta Med 69:413-419

20. Singh G, Kapoor IPS, Singh P, de Heluani CS, de Lampasona MP, Catalan CAN (2008) Chemistry, antioxidant and antimicrobial investigations on essential oil and oleoresins of Zingiber officinale. Food Chem Toxicol 46: 3295-3302

21. Katalinic $V$, Milos M, Kulisic T, Jukic M (2006) Screening of 70 medicinal plant extracts for antioxidant capacity and total phenols. Food Chem 94:550-557

22. Senguttuvan J, Paulsamy S, Karthika K (2014) Phytochemical analysis and evaluation of leaf and root parts of the medicinal herb, Hypochaeris radicata $\mathrm{L}$. for in vitro antioxidant activities. Asian Pac J Trop Biomed 4: S359-S367

23. Saeed N, Khan MR, Shabbir M (2012) Antioxidant activity, total phenolic and total flavonoid contents of whole plant extracts Torilis leptophylla L. BMC Complement Altern Med. https://doi.org/10.1186/1472-6882-12-221

24. Bhatti HN, Khera RA (2012) Biological transformations of steroidal compounds: a review. Steroids 77:1267-1290

25. Brown JP (1980) A review of the genetic effects of naturally occuring flavonoids, anthraquinones and related compounds. Mutat Res 75:243-277

26. Mahdi-Pour B, Jothy SL, Latha LY, Chen Y, Sasidharan S (2012) Antioxidant activity of methanol extracts of different parts of Lantana camara. Asian Pac J Trop Biomed 2:960-965 
27. Gandía-Herrero F, Escribano J, García-Carmona F (2009) The role of phenolic hydroxy groups in the free radical scavenging activity of betalains. J Nat Prod 72:1142-1146

28. Leja M, Kaminska I, Kramer M, Maksylewicz-kaul A, Kammerer D, Carle R, Baranski R (2013) The content of phenolic compounds and radical scavenging activity varies with carrot origin and root color. Plant Foods Hum Nutr 68:163-170

\section{Publisher's Note}

Springer Nature remains neutral with regard to jurisdictional claims in published maps and institutional affiliations.

Submit your manuscript to a SpringerOpen ${ }^{\circ}$ journal and benefit from:

- Convenient online submission

- Rigorous peer review

- Open access: articles freely available online

- High visibility within the field

- Retaining the copyright to your article

Submit your next manuscript at $\boldsymbol{\nabla}$ springeropen.com 